\title{
Meningkatkan Prestasi Belajar Seni Rupa Materi Seni Rupa Murni Dengan Menerapkan Model Pembelajaran Learning By Doing Pada Siswa Kelas IX.8 SMP Neger 1 Praya Tahun Pelajaran 2017/2018
}

\author{
Tri Widiyati \\ Guru Seni rupa SMPN 1 Praya
}

\begin{abstract}
Abstrak. Penelitian ini berdasarkan permasalahan: (a) Apakah pembelajaran learning by doing berpengaruh terhadap prestasi belajar Seni Rupa ? (b) Seberapa tinggi tingkat penguasaan materi pelajaran Seni Rupa dengan diterapkannya metode pembelajaran learning by doing? Tujuan dari penelitian ini adalah: (a) Untuk mengungkap pengarus pembelajaran learning by doing terhadap hasil belajar Seni Rupa . (b) Ingin mengetahui seberapa jauh pemahaman dan penguasaan mata pelajaran Seni Rupa setelah diterapkannya pembelajaran learning by doing Penelitian ini menggunakan penelitian tindakan (action research) sebanyak tiga putaran. Setiap putaran terdiri dari empat tahap yaitu: rancangan, kegiatan dan pengamatan, refleksi, dan refisi. Sasaran penelitian ini adalah siswa Kelas IX. Data yang diperoleh berupa hasil tes formatif, lembar observasi kegiatan belajar mengajar. Dari hasil analis didapatkan bahwa prestasi belajar siswa mengalami peningkatan dari siklus I sampai siklus III yaitu, siklus I (54\%), siklus II (73\%). Simpulan dari penelitian ini adalah metode learning by doing dapat berpengaruh positif terhadap motivasi belajar Siswa Kelas IX, serta model pembelajaran ini dapat digunakan sebagai salah satu alternative Seni Rupa.
\end{abstract}

Kata Kunci: Seni Rupa, Learning By Doing

\section{PENDAHULUAN}

\section{Latar Belakang Masalah}

Dalam pendidikan pengembangan kurikulum sangat diperlukan. Hal ini terkait dengan orientasi pembelajaran dari waktu terus berkembang. Keperluan pembelajran yang menerapkan model kekinian dan berorientasi pada pembelajaran untuk kehidupan sangatlah diperlukan. Oleh karena itu para praktisi pendidikan selalu mengevaluasi maslah kurikulum ini.

Dalam model kurikulum, model-model dapat digunakan untuk menentukan materi (konten) pembelajaran dan metode-metode dalam pencapaian materi tersebut, dalam arti bahwa model memberikan kerangka untuk menentukan pilihan. Dengan menguasai berbagai model bermanfaat dalam situasi pembejaran tertentu.

Sebagaimana dikutip Utami Munandar dalam Bukunya Pengembangan Kreativitas Anak Berbakat, Talents dan taylor mengemukakan bahwa tidak hanya bakat akademis yang perlu dipupuk dan dihargai dalam sekolah, dalam modelnya dapat dibedakan enam talenta yang dapat dikembangkan di sekolah.
Seperti yang tertuang dalam curriculum guide, program disusun untuk mengajar konten akademik, kreativitas, ketrampilan merencanakan, komunikasi, prediksi, dan pengambilan keputusan.

Lingkungan yang paling berpengaruh dalam membentuk kreativitas anak adalah sekolah, karena didalamnya terjadi proses interaksi edukatif yang mengharuskan siswa mengikuti sistem aturan yang ada. Sekolah yang baik akan mengedepankan kenyamanan belajar bagi siswanya, karenanya guru mempunyai dampak yang besar, tidak hanya pada prestasi pendidikan anak, tetapi juga pada sikap.

Disamping itu guru memberi dampak yang besar tidak hanya pada prestasi pendidikan anak, tetapi juga pada sikap terhadap sekolah dan terhadap belajar pada umumnya. Dalam upaya memunculkan, merangsang, dan memupuk pertumbuhan kreativitas guru harus menata sikap dan falsafah mengajarnya.

Anak akan bisa memahami materi tersebut saat metode pembelajaran learning by doing ini di terapkan oleh 
guru. Sehingga out put nya juga akan maksimal.

Berdasarkan latar belakang diatas, maka peneliti mengambil Judul:" Meningkatkan Prestasi Belajar Seni Rupa Materi Seni Rupa Murni dengan Menerapkan Model Pembelajaran Learning By Doing pada Siswa Kelas IX.8 SMP Negeri 1 Praya Tahun Pelajaran 2017/2018

\section{Rumusan Masalah}

Merujuk pada uraian latar belakang di atas, dapat dirumuskan masalah bagaimanakah ; ;Meningkatkan Prestasi Belajar Seni Rupa Materi Seni Rupa Murni dengan Menerapkan Model Pembelajaran Learning By Doing pada Siswa Kelas IX.8 SMP Negeri 1 Praya Tahun Pelajaran 2017/2018

\section{Tujuan Penelitian}

Berdasar atas rumusan masalah di atas, maka tujuan dilaksanakan penelitian ini adalah:

Untuk Meningkatkan Prestasi Belajar Seni Rupa Materi Seni Rupa Murni dengan Menerapkan Model Pembelajaran Learning By Doing pada Siswa Kelas IX.8 SMP Negeri 1 Praya Tahun Pelajaran 2017/2018.

\section{KAJIAN PUSTAKA}

\section{Model Pembelajaran Learning By Doing}

Belajar bagi kehidupan manusia menjadi bagian yang sangat penting, karena manusia diciptakan sebagai pengelola dunia (khalifah fil ardi). Secara bertahap mereka akan mengalami fase pembelajaran yang didasarkan pada pengalaman. Sebagai ilustrasi terdekat adalah bayi manusia yang dilahirkan, jika tidak mendapat bantuan dari manusia dewasa yang lain, tidak belajar, niscaya binasalah ia. Ia tidak mampu mengembangkan naluri/intrinsik dan potensipotensi yang diperlukan untuk kelangsungan hidupnya tanpa pengaruh dari luar.

Beberapa pendapat tentang pengertian belajar banyak disebutkan, diantaranya, Hilgard dan Bower dalam bukunya Theories of Learning yang dikutip oleh Ngalim Purwanto dalam Psikologi Pendidikan bahwa belajar berhubungan dengan perubahan tingkah laku seseorang terhadap situasi tertentu yang disebabkan oleh pengalaman berulang-ulang dalam situasi tersebut, dimana perubahan tingkah laku itu tidak dapat dijelaskan atau dasar kecenderungan respon pembawaan, kematangan, atau keadaan-keadaan sesaat seseorang (misalnya kelelahan, pengaruh obat dan sebagainya).

Lebih lanjut Piaget berpendapat seperti yang disadur Dimyati dan Mudjiono bahwa pengetahuan dibentuk oleh individu. Sebab individu melakukan interaksi terus menerus dengan lingkungan yang selalu mengalami perubahan, sehingga fungsi intelek semakin berkembang. Pengetahuan dibangun atas dasar tiga bentuk, yaitu pengetahuan fisik, pengetahuan logikamatematik, dan pengetahuan sosial.

Sedangkan prosesnya didasarkan tiga fase, yaitu fase eksplorasi, pengenalan konsep, dan aplikasi konsep. Fase eksplorasi mengarahkan siswa mempelajari gejala dengan bimbingan, fase pengenalan konsep adalah mengenalkan siswa akan konsep yang berhubungan dengan gejala, sedangkan fase aplikasi konsep, siswa menggunakan konsep untuk meneliti gejala lain lebih lanjut.

Uraian tersebut merupakan proses internal yang kompleks dan melibatkan ranah kognitif, afektif dan psikomotorik. Kompleksitas belajar dapat dipandang dari dua subyek, yaitu dari siswa dan dari guru. Siswa secara lagsung mengalami proses mental dalam menghadapi bahan belajar berupa; keadaan alam, hewan, tumbuhtumbuhan, manusia dan bahan yang telah terhimpun dalam literatur. Proses belajar diamati dari prilaku belajar tentang sesuatu hal, proses ini dapat diamati secara tidak langsung, yaitu proses internal siswa tidak dapat diamati langsung, tetapi dapat dipahami oleh guru.

Sebagai upaya merancang, mengelola dan mengembangkan program pembelajaran dalam kegiatan mengajar, guru diharapkan mampu mengenal faktor-faktor penentu kegiatan pembelajaran, diantaranya: a. Karakteristik tujuan, yang mencakup pengetahuan, ketrampilan, dan nilai yang ingin dicapai atau ditinggalkan sebagai hasil kegiatan. b. Karakteristik mata pelajaran/bidang studi, meliputi tujuan isi pelajaran, urutan, dan cara mempelajarinya. c. Karakteristik siswa, meliputi karakteristik 
prilaku masukan kognitif dan afektif, usia, jenis kelamin dan yang lain. d. Karakteristik guru, meliputi filosofinya tentang pendidikan dan pembelajaran, kompetensinya dalam teknik pembelajaran, kebiasaanya, pengalaman kependidikanya dan yang lain.

Hubungan faktor-faktor penentu tersebut merupakan satu kesatuan yang tidak dapat dipisahkan. Peran guru dalam hal ini adalah tetap konsisten untuk mempertimbangkan faktor eksternal (diluar dari guru), faktor internal (dalam diri guru), sehingga teknik-teknik pembelajaran efektif dapat dilaksanakan.

Pola pengajaran guru berkaitan erat dengan pilihan metode, jika bahan pelajaran disajikan secara menarik besar kemungkinan motivasi belajar siswa akan meningkat.

Sesuai yang disebutkan dalam Kamus Besar Seni Rupa bahwa model adalah acuan dari sesuatu yang akan dibuat atau dihasilkan.

Metode yang dimaksud didasarkan pada model pembelajaran yang dipakai, model pembelajaran dalam hal ini diartikan sebagai acuan proses perubahan tingkah laku yang dihasilkan melalui pengalaman. Keterlibatan langsung anak didik dalam proses edukatif menjadi pengalaman terarah yang diharapkan mengakar pada diri anak didik. Karena pengalaman memberikan arah positif pada seleksi dan organisasi terhadap berbagai materi dan metode pendidikan yang cocok, inilah upaya untuk memberikan arah baru bagi tugas sekolah.

Dengan demikian belajar merupakan proses yang tidak bertujuan mengembangkan secara spontan segala potensi bawaan, melainkan bertujuan merangsang proses perkembangan yang berlangsung melalui suatu urutan tahap yang tetap, dengan cara menyajikan berbagai masalah dan konflik riil yang dapat diatasi atau diselesaikan oleh anak secara aktif "by doing it".

\section{Bentuk-bentuk Learning by Doing}

Interaksi edukatif selayaknya dibangun guru berdasarkan penerapan aktivitas anak didik, yaitu belajar sambil melakukan (Learning by doing). Melakukan aktivitas atau bekerja adalah bentuk pernyataan dari anak didik bahwa pada hakekatnya belajar adalah perubahan yang terjadi setelah melakukan aktivitas atau bekerja. Pada kelas-kelas rendah di Sekolah Dasar, aktivitas ini dapat dilakukan sambil bermain sehingga anak didik akan aktif, senang, gembira, kreatif serta tidak mengikat.

Lebih lanjut guru memposisikan sebagai penunjuk jalan saja, pengamat tingkah laku anak, dengan pengamatanya tersebut ia dapat menentukan masalah yang akan dijadikan pusat minat anak. Kondisi demikian merupakan perbaikan dari paradigma pendidikan lama, yang tidak memberikan ruang bagi siswa. Di Sekolah kuno murid hanya mendengarkan. It is made for listening! Kata Dewey seperti yang dikutip Muis Sad Iman dalam bukunya Pendidikan Partisipatif. Keadaan seperti itu wajib dirubah. Anak harus bersama-sama, menyelidiki dan mengamati sendiri, berfikir dan menarik kesimpulan sendiri, membangun dan menghiasi sendiri sesuai dengan insting yang ada padanya. Tampaklah disini anak belajar sambil bekerja dan bekerja sambil belajar. Inilah makna istilah Learning by doing yang dikehendaki oleh Dewey dalam do school.

Keterlibatan siswa tidak hanya sebatas fisik semata, tetapi lebih dari itu terutama adalah keterlibatan mental emosional, keterlibatan dengan kegiatan kognitif dalam pencapaian dan perolehan pengetahuan, penghayatan dan internalisasi nilai-nilai dalam pembentukan sikap dan nilai, dan juga pada saat mengadakan latihanlatihan dalam pembentukan ketrampilan.

Pada aspek lain guru juga menkondisikan anak didik dengan menggunakan bentuk-bentuk pengajaran dalam konteks learning by doing, diantaranya: a) Menumbuhkan motivasi belajar anak Motivasi berkaitan erat dengan emosi, minat, dan kebutuhan anak didik. Upaya menumbuhkan motivasi intrinsik yang dilakukan guru adalah mendorong rasa ingin tahu, keinginan mencoba, dan sikap mandiri anak didik. Sedangkan bentuk motivasi ekstrinsik adalah dengan memberikan rangsangan berupa pemberian nilai tinggi atau hadiah bagi siswa berprestasi dan sebaliknya. b) Mengajak anak didik 
beraktivitas Adalah proses interaksi edukaktif melibatkan intelek-emosional anak didik untuk meningkatkan aktivitas sehingga motivasi akan meningkat. Bentuk pelaksanaanya adalah mengajak anak didik melakukan aktivitas atau bekerja di laboratorium, di kebun/lapangan sebagai bagian dari eksplorasi pengalaman, atau mengalami pengalaman yang sama sekali baru. c) Mengajar dengan memperhatikan perbedaan individual.

Proses kegiatan belajar mengajar dilakukan dengan memahami kondisi masing-masing anak didik. Tidak tepat jika guru menyamakan semua anak didik karena setiap anak didik mempunyai bakat berlainan dan mempunyai kecepatan belajar yang bervariasi. Seorang anak didik yang hasil belajarnya jelek dikatakan bodoh. Kemudian menyimpulkan semua anak didik yang hasil belajarnya jelek dikatakan bodoh. Kondisi demikian tidak dapat dijadikan ukuran, karena terdapat beberapa faktor penyebab anak memiliki hasil belajar buruk, antara lain; faktor kesehatan, kesempatan belajar dirumah tidak ada, sarana belajar kurang, dan sebagainya. d) Mengajar dengan umpan balik Bentuknya antara lain; umpan balik kemampuan prilaku anak didik (perubahan tigkah laku yang dapat dilihat anak didik lainnya, pendidik atau anak didik itu sendiri), umpan balik tentang daya serap sebagai pelajaran untuk diterapkan secara aktif. Pola prilaku yang kuat diperoleh melalui partisipasi dalam memainkan peran (role play). e) Mengajar dengan pengalihan Pengajaran yang mengalihkan (transfer) hasil belajar kedalam situasi-situasi nyata. Guru memilih metode simulasi. (f) Penyusunan pemahaman yang logis dan psikologis Pengajaran dilakukan dengan memilih metode yang proporsional. Dalam kondisi tertentu guru tidak dapat meninggalkan Rumah pendidikan Sciena Madani metode ceramah maupun metode pemberian tugas kepada anak didik. Hal ini dilakukan sesuai dengan kondisi materi pelajaran.

\section{Peran Pengalaman dalam Pembelajaran}

Berangkat dari refleksi model pendidikan tradisional yang bersifat dogmatis yang hanya mewariskan segala pengetahuan terhadap generasi baru tanpa didasarkan pada pengujian kritis terhadap prinsip-prinsip fundamentalnya, tidaklah berlebihan jika John Dewey memberikan pemikiran bahwa pendidikan harus mempunyai perubahan orientasi, yaitu pendidikan gaya baru yang menekankan kebebasan pelajar.

Alasan tersebut didasarkan pada pandangan terhadap pendidikan gaya lama yang lebih memaksakan pengetahuan dan jauh dari nilai penunjukan bagi pengalaman pribadi. Anggapan terhadap ketidakpastian itu terdapat suatu kerangka acuan yang tetap, yaitu hubungan organis antara pendidikan dan pengalaman pribadi, atau bahwa filsafat baru mengenai pendidikan itu mengikatkan dirinya pada sejenis filsafat empiris dan eksperimental.

Pengalaman secara kualitas dapat dibedakan menjadi dua aspek, aspek pertama ialah aspek langsung, yaitu menyenangkan dan tidak menyenangkan. Aspek kedua adalah pengaruhnya atas berbagai pengalaman kemudian. Uraian terakhir merupakan prinsip yang melandasi mengapa pendidikan berkaitan dengan pengalaman, dan disisi lain memberikan inspirasi bagi guru untuk menata beberapa jenis pengalaman dengan terus merangsang kegiatannya. Sehingga pendidikan yang didasarkan atas pengalaman lebih memilih jenis pengalaman sekarang yang berpengaruh secara kreatif dan produktif dalam seluruh pengalaman berikutnya.

Seiring mengalirnya arus pengalaman yang disebut oleh John Dewey dengan "eksperience continum" atau kesatuan rangkaian pengalaman, terdapat dua macam proses, yaitu proses mengetahui dan proses evolusi (terjadi berangsur-angsur). Sedangkan kelanjutan dari pengalaman mempunyai makna ganda: (a) dalam suatu waktu tertentu, bermacam ragam aspek pengalaman saling berhubungan, (b) sepanjang waktu pengalaman berlanjut, sebagai rentetan kejadian.

Disinilah proses refleksi
pengalaman berlangsung, pengalaman yang kurang berpihak dan kurang menguntungkan bagi pedagogis akan dieliminir untuk kemudian mencoba 
menciptakan pengalaman yang sama sekali baru. Keberadaan pengalaman dalam pendidikan didasarkan pada kebiasaan, jika ditinjau dari segi biologis ciri dasar dari kebiasaan adalah bahwa setiap pengalaman yang diperagakan dan dialami akan mengubah orang yang bertindak dan menjalani pengalaman tersebut, sementara modifikasinya mempengaruhi kualitas seluruh pengalaman berikutnya. Prinsip ini meliputi proses pembentukan berbagai sikap emosional dan intelektual, yaitu kepekaan dasar dan segala cara menanggulangi serta menanggapi semua situasi yang kita jumpai dalam hidup.

\section{Proses Pembelajaran}

Proses pembelajaran pada hakekatnya adalah interaksi guru dengan murid dalam rangka menyampaikan bahan pelajaran kepada siswa untuk mencapai tujuan pengajaran.

Dengan demikian belajar mengajar harus bernilai normatif, yaitu mengandung sejumlah nilai yang mampu mengubah tingkah laku, sikap dan perbuatan anak didik menjadi lebih baik, dewasa, dan bersusila. Proses interaksi edukatif melibatkan komunikasi aktif dua arah antara guru dan anak didik, aktif dalam arti sikap, mental, dan perbuatan. Dalam sistem pengajaran dengan pendekatan ketrampilan proses, anak didik dituntut lebih aktif daripada guru. Guru hanya berperan sebagai pembimbing dan fasilitator.

Dalam menyusun program pengajaran guru dapat mengacu pada pendapat beberapa pakar pendidikan sebagaimana dikutip Dimyati dan Mudjiono dalam Bukunya Belajar dan Pembelajaran, diantaranya:

\section{Skinner}

Skinner berpandangan bahwa belajar adalah suatu perilaku. Pada saat orang belajar, maka responya menjadi lebih baik. Sebaliknya, apabila ia tidak belajar maka responya akan menurun. Dalam menerapkan teori skinner, guru perlu memperhatikan dua hal penting, yaitu pemilihan stimulus yang diskriminatif, dan penggunaan penguatan. Dengan demikian diperlukan pemilihan respon pada ranah kognitif atau afektif.
Langkah-langkah pembelajaran berdasarkan teori kondisioning operan adalah: 1). Mempelajari keadaan kelas. Guru mencari dan menemukan prilaku positif dan prilaku negatif siswa yang kemudian memperkuat prilaku positif dan mengeliminir prilaku negatif. 2). Membuat daftar penguat positif. Guru mencari prilaku yang lebih disukai siswa, prilaku yang kena hukuman, dan kegiatan luar sekolah yang dapat dijadikan penguat. 3). Memilih dan menentukan urutan tingkah laku yang dipelajari serta jenis penguatanya. 4). Membuat program pembelajaran. Berisi urutan prilaku yang dikehendaki, penguatan, waktu mempelajari prilaku, dan evaluasi. Dalam melaksanakan program pembelajaran, guru mencatat prilaku dan penguat yang berhasil dan tidak berhasil. Ketidakberhasilan menjadi catatan penting bagi modifikasi prilaku selanjutnya.

Tahap Evaluasi

Menilai sejauhmana pengetahuan yang diperoleh siswa dapat dimanfaatkan untuk memahami dan merespon terhadap gejala-gejala lingkungan yang sedang dihadapi.

Tahapan proses pembelajaran harus disesuaikan dengan hasil yang diharapkan, motivasi belajar, minat, keinginan untuk mengetahui dan dorongan untuk menemukan sendiri. Dalam proses pembelajaran motivasi mempunyai peranan penting, karena merupakan tenaga yang menggerakkan dan mengarahkan aktivitas seseorang. Dengan demikian motivasi dapat menjadi tujuan dan alat dalam pembelajaran. Sebagai tujuan, guru diharapkan mampu mengkondisikan kegiatan intelektual dan estetik agar siswa tertarik dalam proses pembelajaran. Sebagai alat, motivasi merupakan salah satu faktor penentu keberhasilan belajar siswa dalam bidang pengetahuan, nilai-nilai dan ketrampilan.

Sebagai upaya menumbuhkan motivasi belajar siswa dibutuhkan proses pembelajaran yang tenang dan menyenangkan, hal tersebut tentu saja menuntut aktivitas dan kreativitas guru dalam menciptakan lingkungan yang kondusif. Ukuran kualitas pembelajaran dapat dilihat dari segi proses dan dari segi 
hasil. Dari segi proses apabila seluruh atau setidak-tidaknya sebagian besar (75\%) peserta didik terlibat secara aktif, baik fisik, mental maupun sosial dalam proses pembelajaran, antara lain menunjukkan kegairahan belajar yang tinggi, semangat belajar yang besar, dan rasa percaya pada diri sendiri. Sedangkan dari segi hasil, terjadinya perubahan tingkah laku positif dalam diri anak didik seluruhnya atau setidak-tidaknya sebagian besar (75\%).

\section{Materi/bahan pembelajaran}

Bahan pelajaran adalah substansi yang akan disampaikan dalam interaksi edukatif, karenanya guru harus mempersiapkan dan menguasai bahan pelajaran pokok dan bahan pelajaran pelengkap. Bahan pelajaran pokok adalah bahan pelajaran menyangkut mata pelajaran yang diampu guru sesuai kompetensinya. Sedangkan bahan pelajaran pelengkap atau penunjang adalah bahan pelajaran yang dapat membuka wawasan guru agar dalam mengajar dapat menunjang penyampaian bahan pelajaran pokok.

Bahan belajar dapat berupa benda dan isi pendidikan, diantaranya berkaitan dengan pengetahuan, prilaku, nilai, sikap, dan metode pemerolehan. Guru berperan selektif dalam memilih bahan pelajaran dengan mempertimbangkan faktor berikut: (a) Bahan belajar harus sesuai dengan sasaran belajar. Jika tidak sesuai, maka perlu bahan pengganti yang sederajat dengan program. (b) Tingkat kesukaran bahan belajar, jika bahan belajar tergolong sukar maka guru perlu "membuat mudah"(c) Bahan belajar harus sesuai dengan strategi belajar mengajar. Guru harus menyesuaikan strategi belajar mengajar dengan bahan belajar, (d) Evaluasi hasil belajar harus sesuai dengan bahan belajar. Kemampuan pada ranah kognitif, afektif, psikomotorik harus terkandung dalam bahan belajar.

Ketika kita menengok pada pendidikan di Taman Kanak-kanak, program kegiatan belajarnya merupakan kesatuan program kegiatan yang utuh, yaitu berisi bahan-bahan pembelajaran yang disusun menurut pendekatan tematik. Pendekatan tematik diartikan sebagai organisasi dari kurikulum dan pengalaman belajar melalui pemilihan topik. Dengan demikian bahan tersebut merupakan tema-tema yang dikembangkan lebih lanjut oleh guru menjadi program kegiatan pembelajaran yang operasional.

Prinsip diatas menjadi dasar untuk mengembangkan kurikulum yang terintegrasi, sebagai gambarannya adalah ketika anak belajar diluar ruangan, mereka akan belajar segalanya. Menurut Katz dan Chard seperti yang dikutip Soemiarti Patmonodewo dalam bukunya Pendidikan Anak Prasekolah, guru harus mempertimbangkan beberapa kriteria dalam memilih tema pembelajaran yaitu: (a) Keterkaitan tema yang dipelajari anak dengan kehidupanya, dengan kata lain apa yang akan dipelajari anak harus mempunyai arti (b) Guru harus mengkaitkan tema dengan kemungkinan bagi anak untuk sekaligus dapat belajar membaca, menulis dan berhitung yang benar-benar mempunyai arti bagi anak.( c) Adanya buku-buku dan informasi lain yang dapat mendukung dalam pemilihan tema (d) Minat guru. Dengan keberadaan minat maka guru menginginkan untuk memberikan bimbingan kepada anak (e) tema dipilih berdasarkan kurun waktu tertentu, mungkin musim-musim yang biasanya terjadi dalam satu tahun.

\section{Sarana/media Pembelajaran}

Media merupakan salah satu faktor yang menentukan keberhasilan pengajaran, karena membantu guru dalam menyampaikan materi pelajaran dan meningkatkan efisiensi proses serta mutu hasil pendidikan.

Media dan sumber belajar dapat ditemukan dengan mudah dalam sawah percobaan, kebun bibit, kebun binatang, tempat wisata, museum, perpustakaan umum, surat kabar, majalah, radio, sanggar seni, sanggar olah raga, dan televisi. Disamping itu buku pelajaran, buku bacaan, dan laboratorium sekolah juga tersedia semakin baik. Guru dapat memanfaatkan media dan sumber belajar dengan mempertimbangkan efektifitasnya sebagai berikut: a) Sejauh mana media dan sumber belajar bermanfaat dalam mencapai sasaran belajar., b) Sejauhmana manfaat isi pengetahuan yang 
terdapat dalam surat kabar, majalah, radio, televisi, museum dan kantor-kantor untuk pokok bahasan tertentu., c) Apakah isi pengetahuan di kebun bibit, kebun binatang, perpustakaan umum bermanfaat bagi pokok bahasan tertentu. Jika ya, maka guru harus memanfaatkan dan membuat program karya wisata.

Penggunaan media/sarana pembelajaran bagi anak prasekolah harus dipersiapkan guru sedemikian rupa, karena menyangkut kebutuhan ruang bagi masingmasing anak baik di dalam maupun diluar ruang belajar.

Disisi lain terdapat klasifikasi tentang penyiapan peralatan untuk anak usia awal menurut area perkembanganya, yaitu: 1) Perkembangan fisik, perlengkapan penunjangnya adalah alat panjatan, mainan beroda, balok-balok, ban, bola, sepatu tali, mute untuk dironce, kartu dengan pola, papan keseimbangan, tangga, gunting, alat perkayuan, alat-alat untuk main pasir, serta alat lain yang memungkinkan anak mengembangkan koordinasi otot besar dan halus. 2) Perkembangan sosial, memerlukan alat yang berhubungan dengan kantor pos, alat yang biasa dijual di toko kelontong, alat rumah tangga, dan alat lain yang mendorong anak untuk bermain atau bekerja sama. 3) Perkembangan intelektual, memerlukan alat berupa: binatang, tanaman, alat untuk dimanipulasi, pasir, air, kayu balok, papan titian, gelas, ukuran, alat mainan yang berpasangan, buku, daun, bunga, puzzle, dan sebagainya. 4) Perkembangan kreativitas, memerlukan berbagai alat gambar/lukis, berbagai macam ukuran, bentuk dan kualitas kertas, pensil berwarna, lilin, biji-bijian, gunting, krayon, sedotan dan seterusnya. 5) Perkembangan bahasa, membutuhkan buku, tape, kartu yang dapat mengembangkan bahasa, cerita, bermain jari-jemari, boneka, wayang, buku buatan anak sendiri, baju, kunjungan luar, situasi sosial, bermain puraputa, kesempatan untuk bertemu dengan orang lain. 6) Perkembangan emosi, memerlukan alat yang dapat membuat anak berhasil melakukan, manantang tetapi tidak membuat frustasi, mainan yang membuat anak mampu.

\section{Peningkatan Kreativitas Anak}

Dari segi bahasa kreativitas anak atau dalam bahasa Inggris "creativity" berarti kemampuan untuk mencipta, daya cipta. Sedang menurut istilah kreativitas berarti kemampuan menghasilkan bentuk baru dalam seni atau dalam permesinan atau dalam memecahkan masalah-masalah dengan metode baru.

Dengan demikian kreativitas merupakan kemampuan untuk mencipta produk baru, ciptaan itu tidak seluruhnya baru, mungkin saja kombinasinya, sedangkan unsur-unsurnya sudah ada sebelumnya. Kreativitas mempunyai ciri-ciri non kecakapan seperti rasa ingin tahu, senang mengajukan pertanyaan pertanyaan dan selalu ingin mencari pengalaman baru.

\section{Berikut unsur-unsur dalam kreativitas:}

Dalam pengembanganya kreativitas memerlukan pikiran yang berdaya, dalam arti menghindarkan diri dari jebakan keadaan, namun menjadi imajinatif dalam upaya menemukan sebuah jalan keluar atas sebuah permasalahan atau dalam upaya untuk memiliki rasa memiliki atas sebuah teka-teki.

Lebih lanjut Elliot memaparkan bahwa imajinasi dan kreativitas adalah sama, karenanya dapat dikatakan bahwa pemecahan masalah masuk dalam imajinasi dalam upaya melihat kemungkinan-kemungkinan.

Pikiran untuk mencipta merupakan esensi dari kreativitas, sebagaimana Gardner menyebut bahwa pikiran untuk mencipta adalah sebuah frase yang mengandung dinamisme dan cakupan yang jelas. Secara lebih gamblang, dijelaskan bahwa orang kreatif adalah: a) Berfikir untuk diri mereka sendiri, b) Menghabiskan banyak waktu untuk mengintegrasikan pikiran mereka dengan apa yang ada diluar mereka, c) Berupaya membuka pikiran mereka dan yang lain kepada hal baru, d) Mengupayakan dengan senantiasa menuju (to-ing) dan mengarahkan (fro-ing) dari dalam diri mereka keluar.

Kreativitas senantiasa membuka diri untuk berpikir integratif berdasar pengalaman sehingga merupakan kunci pencipta yang berhasil. Disamping itu motivasi intrinsik juga mempengaruhi pembentukan individu 
kreatif. Karena karakter individu kreatif adalah mempunyai keinginan untuk menghasilakan ide atau karya demi kepuasan diri dan tidak ada tekanan dari luar. Pengaruh motivasi intrinsik dalam pengembangan kreativitas berlangsung dalam kondisi-kondisi mental tertentu. Beberapa kondisi dalam diri untuk menjadi kreatif adalah: a) Terbuka untuk pengalaman , b) Sebuah tempat evaluasi internal (dalam kaitanya dengan diri seseorang itu sendiri), c) Sebuah kemampuan untuk bermain dengan elemen-elemen dan konsep-konsep (Kemampuan untuk bermain).

\section{Materi Pembelajaran Seni Rupa}

Seni Rupa Murni

Karya seni dapat tampil dalam berbagai wujud, bentuk, dan sifat. Hal ini terjadi karena karya seni mempunyai cakupan yang sangat luas. Kemampuan seorang seniman dalam berekspresi juga turut memberikan andil dalam menciptakan beragam karya. Masing-masing seniman mempunyai spesialisasi, teknik, kesukaan, dan pilihan dalam berkarya. Selain itu, setiap seniman juga mempunyai kelebihan yang berbeda antara satu seniman dengan seniman lain.

Seni rupa merupakan cabang seni yang bentuk perwujudannya dapat dilihat dan diraba (visual art). Seni rupa merupakan ungkapan perasaan dan pengalaman artistik seniman, desainer, dan pengrajin yang dapat diwujudkan melalui berbagai media, bahan, teknik, bentuk, dan sifat sehingga dapat menghasilkan sebuah karya seni.

Bentuk karya seni rupa terdiri atas bentuk dua dimensi (dwimatra) dan tiga dimensi (trimatra). Bentuk dua dimensi memiliki ukuran panjang dan lebar atau hanya dapat dinikmati dari satu sudut pandang. Contoh seni rupa dua dimensi adalah lukisan, batik, dan ilustrasi. Adapun bentuk karya seni rupa tiga dimensi memiliki ukuran panjang, lebar, dan tinggi sehingga dapat dilihat dari berbagai arah. Contoh karya seni rupa tiga dimensi adalah patung, wayang golek, diorama,

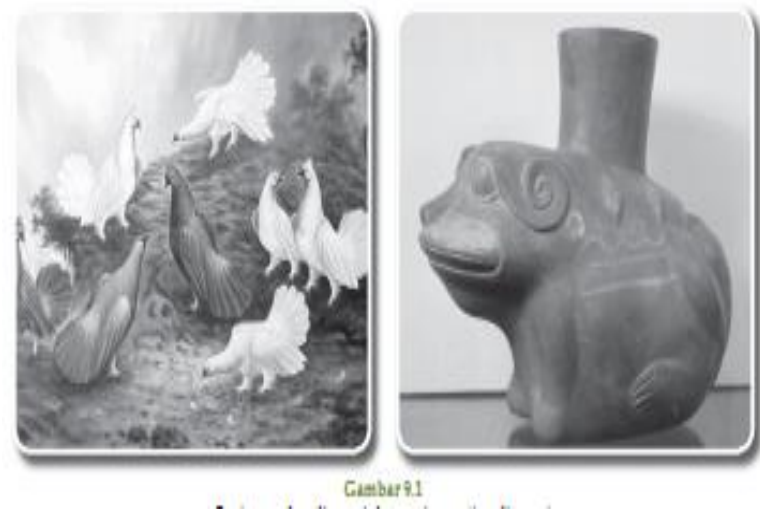

Secara umum seni rupa terbagi menjadi dua cabang, yaitu seni rupa murni (pure art/fine art) dan seni murni terapan (applied art). Seni rupa murni dibuat dengan fungsi murni untuk keindahan. Sementara itu, seni rupa terapan dibuat bukan hanya dengan fungsi keindahan, namun dapat digunakan dalam kehidupan sehari-hari. Pada pelajaran ini kamu akan belajar tentang seni rupa murni. Contoh seni rupa murni adalah seni patung dan seni lukis.

Seni lukis adalah seni yang mengekspresikan pengalaman artistik seorang seniman melalui bidang dua dimensi. Para seniman seni lukis memanfaatkan unsur bidang, warna, tekstur, bentuk, nada, komposisi, dan ritma serta ungkapan ide, gagasan, tema, isi, dan perasaan untuk membuat sebuah karya seni. Berdasarkan media, bahan, dan tekniknya, seni lukis dapat dibedakan menjadi lukisan cat minyak, cat air, pastel, arang, fresco, al secco, tempera, azalejo, kolase, kaca, dan batik.

\section{Bahan dan Teknik Pembuatan Patung}

Untuk membuat sebuah patung ada beberapa bahan dan teknik yang digunakan. Berikut ini beberapa di antaranya. 1) Bahan Keras ,2) Bahan Plastis Bahan lunak yang dapat digunakan untuk membuat patung antara lain tanah liat, semen, plastisin, lilin, bubur kertas, sabun, dan gips. Patung dari bahan plastis bisa dibuat dengan teknik membentuk, membutsir, mencetak, modelling, coiling, pijit, dan slabing. 


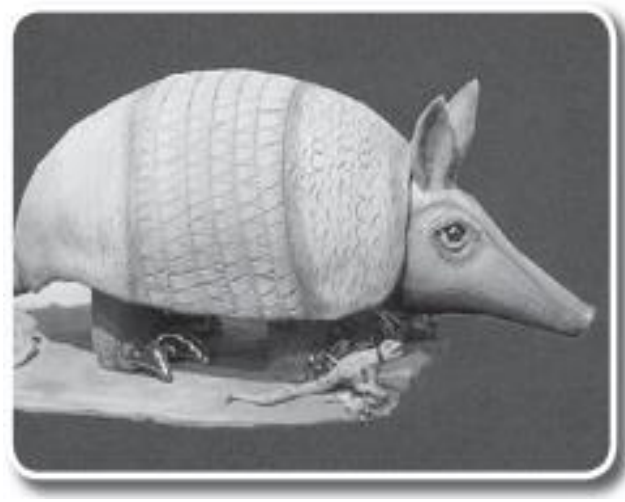

Teknik Membuat Patung

Dalam membuat patung seorang seniman dapat membuat patung dengan berbagai teknik bergantung pada bahan dan keahlian yang dimilikinya. Teknik-teknik tersebut antara lain teknik mengecor, modelling, dan konstruktif.

\section{Sikap Apresiatif terhadap Karya Seni Murni}

Sikap apresiatif terhadap karya seni bisa diwujudkan dengan menghargai karya seni sebagai warisan dan peninggalan yang harus dilestarikan keberadaannya. Tak dipungkiri lagi bahwa sebuah karya seni lahir dari tangan yang penuh bakat. Dari masa ke masa karya seni, baik seni patung, lukis, maupun grafis selalu berubah. Perubahan ini sejalan dengan berubahnya pola pikir manusia, termasuk seniman. Progresivitas seniman dalam berkarya membuat peta perkembangan seni menjadi maju dan berkembang. Hal ini berdampak pada peningkatan kualitas karya mengingat ditemukannya teknik-teknik berkarya yang baru ditambah dengan ketersediaan media berkarya yang semakin mutakhir. Jika kamu perhatikan lebih jauh ternyata lahirnya sebuah karya seni tak lepas dari masa lalu, yaitu masa penuh penemuan yang menjadi cikal bakal timbulnya sebuah karya.

Dalam membuat sebuah karya seni lukis, para seniman menentukan tujuan pembuatan karya tersebut. Tujuan-tujuan yang dipilih oleh para seniman antara lain tujuan religius, magis, simbolis, estetis, komersil, dan ekspresi, Tujuan Religius, Tujuan Magis, Tujuan Simbolis, Tujuan Estetis, Tujuan Komersil, Tujuan Ekspresi

Dalam pembuatan seni patung, para seniman menentukan tujuan pembuatan karya-karyanya. Berikut ini beberapa di antaranya ;tujuan religius. Tujuan monumen. Biasanya patung-patung tersebut bertujuan politis, historis, simbolis, dan filosofis ,Patung ada yang dibuat sebagai tanda kebesaran Raja. ,Patung ada yang dibuat dengan tujuan ekspresif, yaitu patung yang dibuat semata-mata hanya mengutamakan segi ekspr esi estetis, ide, gagasan, dan perasaan seniman saja.

Beberapa seniman patung Indonesia di antaranya Edi Soenarso, Nyoman Nuarta, Saptoto, G. Sidharta, Rita Widagdo, dan I Gusti Nyoman Lempad.

\section{METODOLOGI PENELITIAN \\ Bentuk Penelitian Tindakan}

PTK dapat membantu dalam pengembangan kompetensi guru dalam penyelesaikan masalah. Dalam PTK pembelajaran mencakup kualitas isi, fisiensi, dan efektivitas pembelajaran, proses, dan hasil belajar siswa, serta peningkatan kemampuan pembelajaran akan berdampak pada peningkatan kompetensi kepribadian, sosial, dan profesional guru (Prendergast, 2002).

Lewin (dalam Prendergast, 2002:2) secara tegas menyatakan, bahwa penelitian tindakan kelas merupakan cara guru untuk mengorganisasikan pembelajaran berdasarkan pengalamannya sendiri atau pengalamannya berkolaborasi dengan guru lain. Sementara itu, Calhoun dan Glanz (dalam Prendergast, 2002:2) menyatakan, bahwa penelitian tindakan kelas merupakan suatu metode untuk memberdayakan guru yang mampu mendukung kinerja kreatif sekolah. Di samping itu, Prendergast (2002:3) juga menyatakan, bahwa penelitian tindakan kelas merupakan wahana bagi guru untuk melakukan refleksi dan tindakan secara sistematis dalam pengajarannya untuk memperbaiki proses dan hasil belajar siswa.

\section{Tempat, Waktu dan Subyek Penelitian}

Penelitian ini bertempat di SMPN 1 Praya dilaksanakan pada bulan Agustus s/d Oktober semester ganjil pada siswa-siswi SMPN 1 Praya Kelas IX.8 tahun pelajaran 2017 pada pokok Seni lukis dengan beragam media dan teknik

\section{Rancangan Penelitian}


Menurut pengertiannya, penelitian tindakan adalah penelitian tentang hal-hal yang terjadi di sekelompok masyarakat atau sasaran, dan hasilnya langsung dapat dikenakan pada masyarakat yang bersangkutan (Arikunto, Suharsimi, 2002: 82). Ciri atau karakteristik utama dalam penelitian tindakan adalah adanya partisipasi dan kolaborasi antara peneliti dengan anggota kelompok sasaran. Penelitian tindakan adalah satu strategi pemecahan masalah yang memanfaatkan tindakan nyata dalam bentuk proses pengembangan invovatif yang dicoba sambil jalan dalam mendeteksi dan memecahkan masalah. Dalam prosesnya, pihak-pihakyang terlibat dalam kegiatan tersebut dapat mendukung satu sama lain.

Sesuai dengan jenis penelitian yang dipilih, yaitu penelitian tindakan, maka penelitian ini menggunakan model penelitian tindakan dari kemmis dan Taggert (dalam Arikunto, Suharsimi, 2002: 83) yaitu berbentuk spiral dari siklus yang satu ke siklus yang berikutnya. Setiap siklus meliputi planning (rencana), action (tindakan), observation (pengamatan), dan reflection (refleksi). Langkah pada siklus berikutnya adalah perencanaan yang sudah direvisi, tindakan, pengamatan, dan refleksi. Sebelum masuk pada siklus I dilakukan tindakan pendahuluan yang berupa identifikasi permasalah. Siklus spiral dari tahap-tahap penelitian tindakan kelas dapat dilihat pada gambar berikut :

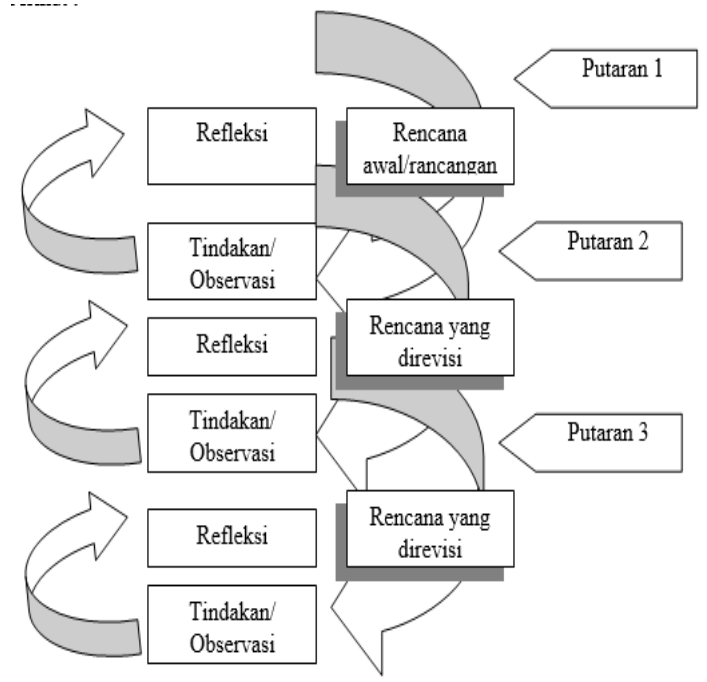

Instrumen Penelitian
Instrumen yang digunakan dalam penelitian ini terdiri dari: ,Silabu, Rencana Pelajaran (RP), Lembar Kegiatan Siswa, Tes formatif. Langkah-langkah analisis butir soal adalah sebagai berikut:

Validitas Tes

Validitas butir soal atau validitas item digunakan untuk mengetahui tingkat kevalidan masing-masing butir soal. Sehingga dapat ditentukan butir soal yang gagal dan yang diterima. Tingkat kevalidan ini dapat dihitung dengan korelasi Product Moment:

$$
r_{x y}=\frac{N \sum X Y-\left(\sum X\right)\left(\sum Y\right)}{\sqrt{\left\{N \sum X^{2}-\left(\sum X\right)^{2}\right\}\left\{N \sum Y^{2}-\left(\sum Y\right)^{2}\right\}}}
$$

(Suharsimi Arikunto, 2001: 72)

Dengan:

$\mathrm{r}_{\mathrm{xy}} \quad$ : Koefisien korelasi product moment

$\mathrm{N}$ : Jumlah peserta tes

$\Sigma \mathrm{Y} \quad$ : Jumlah skor total

$\Sigma \mathrm{X}$ : Jumlah skor butir soal

$\Sigma X^{2}$ : Jumlah kuadrat skor butir soal

$\Sigma X Y$ : Jumlah hasil kali skor butir soal

Reliabilitas

Reliabilitas butir soal dalam penelitian ini menggunakan rumus belah dua sebagai berikut:

$r_{11}=\frac{2 r_{1 / 21 / 2}}{\left(1+r_{1 / 21 / 2}\right)}$ (Suharsimi Arikunto, 2001:

Dengan:

$\mathrm{r}_{11} \quad$ : Koefisien reliabilitas yang sudah disesuaikan

$r_{1 / 21 / 2}$ : Korelasi antara skor-skor setiap belahan tes

Kriteria reliabilitas tes jika harga $\mathbf{r}_{11}$ dari perhitungan lebih besar dari harga $\mathrm{r}$ pada tabel product moment maka tes tersebut reliabel.

Taraf Kesukaran

Bilangan yang menunjukkan sukar dan mudahnya suatu soal adalah indeks kesukaran. Rumus yang digunakan untuk menentukan taraf kesukaran adalah:

$P=\frac{B}{J_{S}} \quad$ (Suharsimi Arikunto, 2001:

208)

Dengan: 
P : Indeks kesukaran

B : Banyak siswa yang menjawab soal dengan benar

Js : Jumlah seluruh siswa peserta tes

Kriteria untuk menentukan indeks kesukaran soal adalah sebagai berikut:

- Soal dengan $\mathrm{P}=0,000$ sampai 0,300 adalah sukar

- Soal dengan $\mathrm{P}=0,301$ sampai 0,700 adalah sedang

- Soal dengan $\mathrm{P}=0,701$ sampai 1,000 adalah mudah

Daya Pembeda

Daya pembeda soal adalah kemampuan suatu soal untuk membedakan antara siswa yang berkemampuan tinggi dengan siswa yang berkemampuan rendah. Angka yang menunjukkan besarnya daya pembeda desebut indeks diskriminasi. Rumus yang digunakan untuk menghitung indeks diskriminasi adalah sebagai berikut:

$D=\frac{B_{A}}{J_{A}}-\frac{B_{B}}{J_{B}}=P_{A}-P_{B}$

(Suharsimi Arikunto, 2001: 211)

Dimana:

D : Indeks diskriminasi

$\mathrm{B}_{\mathrm{A}} \quad$ : Banyak peserta kelompok atas yang menjawab dengan benar

$\mathrm{B}_{\mathrm{B}} \quad$ : Banyak peserta kelompok bawah yang menjawab dengan benar

$\mathrm{J}_{\mathrm{A}} \quad$ : Jumlah peserta kelompok atas

$\mathrm{J}_{\mathrm{B}} \quad$ : Jumlah peserta kelompok bawah

$P_{A}=\frac{B_{A}}{J_{A}}=$ Proporsi peserta kelompok atas

yang menjawab benar.

$P_{B}=\frac{B_{B}}{J_{B}}=$ Proporsi peserta kelompok

bawah yang menjawab benar

Kriteria yang digunakan untuk menentukan daya pembeda butir soal sebagai berikut:

- Soal dengan D $=0,000$ sampai 0,200 adalah jelek

- Soal dengan $\mathrm{D}=0,201$ sampai 0,400 adalah cukup

- $\quad$ Soal dengan $\mathrm{D}=0,401$ sampai 0,700 adalah baik

- Soal dengan $\mathrm{D}=0,701$ sampai 1,000 adalah sangat baik

\section{Metode Pengumpulan Data}

Data-data yang diperlukan dalam penelitian ini diperoleh melalui observasi pengolahan belajar aktif, observasi aktivitas siswa dan guru, dan tes formatif.

\section{Teknik Analisis Data}

Untuk mengetahui keefektivan suatu metode dalam kegiatan pembelajaran perlu diadakan analisa data. Pada penelitian ini menggunakan teknik analisis deskriptif kualitatif, yaitu suatu metode penelitian yang bersifat menggambarkan kenyataan atau fakta sesuai dengan data yang diperoleh dengan tujuan untuk mengetahui prestasi belajar yang dicapai siswa juga untuk memperoleh respon siswa terhadap kegiatan pembelajaran serta aktivitas siswa selama proses pembelajaran.

Untuk menganalisis tingkat keberhasilan atau persentase keberhasilan siswa setelah proses belajar mengajar setiap putarannya dilakukan dengan cara memberikan evaluasi berupa soal tes tertulis pada setiap akhir putaran. Analisis ini dihitung dengan menggunakan statistik sederhana yaitu: Untuk menilai ulangan atau tes formatif Peneliti melakukan penjumlahan nilai yang diperoleh siswa, yang selanjutnya dibagi dengan jumlah siswa yang ada di kelas tersebut sehingga diperoleh rata-rata tes formatif dapat dirumuskan:

$$
\bar{X}=\frac{\sum X}{\sum N}
$$

Dengan $: \bar{X} \quad=$ Nilai rata-rata

semua nilai siswa

$$
\Sigma \mathrm{X}=\text { Jumlah }
$$

Untuk ketuntasan belajar

$$
\Sigma \mathrm{N}=\text { Jumlah siswa }
$$

Ada dua kategori ketuntasan belajar yaitu secara perorangan dan secara klasikal. Berdasarkan petunjuk pelaksanaan belajar mengajar kurikulum 1994 (Depdikbud, 1994), yaitu seorang siswa telah tuntas belajar bila telah mencapai skor $65 \%$ atau nilai 65, dan kelas disebut tuntas belajar bila di kelas tersebut terdapat $85 \%$ yang telah mencapai daya serap lebih dari atau sama dengan $65 \%$. Untuk menghitung persentase ketuntasan belajar digunakan rumus sebagai berikut: 


$$
P=\frac{\sum \text { Siswa.yang.tuntas.belajar }}{\sum \text { Siswa }} \times 100 \%
$$

HASIL PENELITIAN DAN

\section{PEMBAHASAN}

Siklus I

$$
\text { Pelaksanaan kegiatan belajar }
$$

mengajar untuk siklus I dilaksanakan pada bulan Agustus Tahun 2017di Kelas IX.8 jumlah siswa 35 siswa. Dalam hal ini peneliti bertindak sebagai pengajar. Adapun proses belajar mengajar mengacu pada rencana pelajaran yang telah dipersiapkan. Pengamatan (observasi) dilaksanakan bersamaan dengan pelaksanaan belajar mengajar. Pada akhir proses belajar mengajar siswa diberi tes formatif I dengan tujuan untuk mengetahui tingkat keberhasilan siswa dalam proses belajar mengajar yang telah dilakukan.

Adapun data hasil penelitian pada siklus I adalah sebagai berikut. Berdasarkan hasil analisis data aspek-aspek yang mendapatkan kriteria kurang baik adalah memotivasi siswa, menyampaikan tujuan pembelajran, pengelolaan waktu, dan siswa antusias. Keempat aspek yang mendapat nilai kurang baik di atas, merupakan suatu kelemahan yang terjadi pada siklus I dan akan dijadikan bahan kajian untuk refleksi dan revisi yang akan dilakukan pada siklus II.

\section{Siklus II}

Pelaksanaan kegiatan belajar mengajar untuk siklus II dilaksanakan pada Bulan September Tahun 2017 di Kelas IX.8 dengan jumlah siswa 35 siswa. Dalam hal ini peneliti bertindak sebagai pengajar. Adapun proses belajar mengajar mengacu pada rencana pelajaran dengan memperhatikan revisi pada siklus I, sehingga kesalahan atau kekurangan pada siklus I tidak terulang lagi pada siklus II. Pengamatan (observasi) dilaksanakan bersamaan dengan pelaksanaan belajar mengajar.

Pada akhir proses belajar mengajar siswa diberi tes formatif II dengan tujuan untuk mengetahui tingkat keberhasilan siswa dalam proses belajar mengajar yang telah dilakukan. Instrumen yang digunakan adalah tes formatif II. Adapun data hasil penelitian pada siklus II adalah sebagai berikut.

Keterangan : Nilai : Kriteria

$\begin{array}{ll}\text { 1) } & \text { : Tidak Baik } \\ \text { 2) } & \text { : Kurang Baik } \\ \text { 3) } & \text { : Cukup Baik } \\ 4) & \text { : Baik }\end{array}$

Dari hasil analisis data di atas, tanpak aspek-aspek yang diamati pada kegiatan belajar mengajar (siklus II) yang dilaksanakn oleh guru dengan menerapkan metode pembelajarn kooperatif learning by doing mendapatkan penilaian yang cukup baik dari pengamat. Maksudnya dari seluruh penilaian tidak terdapat nilai kurang. Namun demikian penilaian tesebut belum merupakan hasil yang optimal, untuk itu ada beberapa aspek yang perlu mendapatkan perhatian untuk penyempurnaan penerapan pembelajaran selanjutnya. Aspek-aspek tersebut adalah memotivasi siswa, membimbing siswa merumuskan kesimpulan/ menemukan konsep, dan pengelolaan waktu.

\section{Pembahasan}

Ketuntasan Kemampuan berbicara Siswa

Melalui hasil penelitian ini menunjukkan bahwa pembelajaran dengan Metode pembelajaran learning by doing memiliki dampak positif dalam meningkatkan prestasi belajar siswa. Hal ini dapat dilihat dari semakin mantapnya pemahaman siswa terhadap materi yang disampaikan guru (ketuntasan belajar meningkat dari siklus I, II) yaitu masing-masing 54\%, 73\%

Kemampuan Guru dalam Mengelola

Pembelajaran

Berdasarkan analisis data, diperoleh aktivitas siswa dalam proses belajar mengajar dengan menerapkan model pengajaran Metode pembelajaran learning by doing dalam setiap siklus mengalami peningkatan. Hal ini berdampak positif terhadap prestasi belajar siswa yaitu dapat ditunjukkan dengan meningkatnya nilai rata-rata siswa pad setiap siklus yang terus mengalami peningkatan.

Aktivitas Siswa Dalam Pembelajaran

Berdasarkan analisis data, diperoleh aktivitas siswa dalam proses pembelajaran Seni Rupa pada pokok bahasan Seni Rupa 
Murni dengan model pengajaran Metode pembelajaran learning by doing yang paling dominan adalah, mendengarkan/ memperhatikan penjelasan guru, dan diskusi antar siswa/antara siswa dengan guru. Jadi dapat dikatakan bahwa aktivitas siswa dapat dikategorikan aktif.

Sedangkan untuk aktivitas guru selama pembelajaran telah melaksanakan langkah-langkah kegiatan belajar mengajar dengan menerapkan pengajaran konstekstual model pengajaran berbasis masalah dengan baik. Hal ini terlihat dari aktivitas guru yang muncul di antaranya aktivitas membimbing dan mengamati siswa dalam menemukan konsep, menjelaskan materi yang sulit, memberi umpan balik/evaluasi/tanya jawab dimana prosentase untuk aktivitas di atas cukup besar.

\section{KESIMPULAN}

Berdasarkan hasil penelitian yang telah dipaparkan selama tiga siklus, hasil seluruh pembahasan serta analisis yang telah dilakukan dapat disimpulkan sebagai berikut:

1. Metode pembelajaran learning by doing dapat meningkatkan kualitas pembelajaran Seni Rupa.

2. Metode pembelajaran learning by doing memiliki dampak positif dalam meningkatkan prestasi belajar siswa yang ditandai dengan peningkatan ketuntasan belajar siswa dalam setiap siklus, yaitu siklus I (54\%), siklus II $(73 \%)$.

3. Model pengajaran Metode pembelajaran learning by doing dapat menjadikan siswa merasa dirinya mendapat perhatian dan kesempatan untuk menyampaikan pendapat, gagasan, ide dan pertanyaan.

4. Siswa dapat bekerja secara mandiri maupun kelompok, serta mampu mempertanggungjawabkan segala tugas individu maupun kelompok.

5. Penerapan pembelajaran dengan Metode pembelajaran learning by doing mempunyai pengaruh positif, yaitu dapat meningkatkan kreatifitas belajar siswa.

\section{DAFTAR PUSTAKA}

Ngalim Purwanto, Psikologi Pendidikan, PT. Remaja Rosdakarya, Bandung, 2002 ,

imyati dan Mudjiono, Belajar dan Pembelajaran, Rineka Cipta, Jakarta, 2002,

Syaiful Bahari Djamarah, Guru dan Anak Didik dalam Interaksi Edukatif, Rineka Cipta, Jakarta, 2000,

Departemen Pendidikan Nasional, Kamus Besar Seni Rupa Edisi Ketiga, Balai Pustaka, Jakarta, 2002,

Ngalim Purwanto, Op. Cit., Hlm. 84 Rumah pendidikan Sciena Madani John

Dewey, Pendidikan dan Pengalaman, terj. John de Santo, Penerbit Kepel Press, Yogyakarta, 2002,

Syaiful Bahri Djamarah, Op. Cit., Hlm. 186 Rumah pendidikan Sciena Madani Muis Sad Iman, Pendidikan Partisipatif: Menimbang Konsep Fitrah dan Progresivisme John

Dewey, Safiria Insania Press, Yogyakarta, 2004,

Nasution, Berbagai Pendekatan dalam Proses Belajar Mengajar, Bumi Aksara, Jakarta, 2000,

E. Mulyasa, Kurikulum Berbasis Kompetensi; Konsep, Karakteristik, dan Implementasi, Remaja Rosdakarya, Bandung, 2004,

Hagen, Uta. 2002. A. Challenge For the Actor. New York: Scribner.

Hartoko, Dick. 1997. Manusia dan Seni, Yogyakarta: Kanisius.

Pedoman khusus Pengembangan silabus Mata Pelajaran Seni SMA.2003. Departemen

Pendididkan Nasional. Bandung

Poerwadarminta. 2002. Kamus Besar Bahasa Indonesia. Jakarta: Balai Pustaka.

Reading, Mario. Dictionary of Cinema. New York: House of Strauss.

Sachari. Agus. 1986. Seni, Desain dan Teknologi. Bandung: Pustaka.

Sahman, Humar. 1993. Mengenal Dunia seni Rupa. Semarang: IKIP Semarang.

Saraswati. 1982. Membuat Keramik Sederhana. Jakarta: Bharata karya Aksara. 
Sardiyanto. 1991. Pendidikan Seni Rupa.

Tasikmalaya: Diktat Pendidikan

Seni Rupa. 